\title{
Sikap dan Perilaku Komunitas Warga mengenai Maraknya Pedagang Kaki Lima
}

\author{
Neni Yulianita, Yenni Yuniati, Atie Rachmiatie, M.E. Fuady
}

\begin{abstract}
Streetmerchant, famously known in Indonesia as Pedagang Kaki Lima (PKL) raise some problems for the city every year. The city government has tried to locate them in some areas, the amount of PKL has never decreased. From the year of 1997 to 2000, the amount of PKL has increased 56.3\%/year. It means, from around 3.000 PKL in 1997, the amount of PKL has hit a number of 16.880 due to the worsening of economic conditions. This research aimed to study problems concerning PKL and interactions among PKL, city government, and community itself. It is found that opinions of community members toward PKL are varying: some feels uncomfortable, another think that it's not their problems, on the other hand, people admit that they need PKL to supply materials for them.
\end{abstract}

Kata kunci: pedagang kaki lima, tujuh $\mathrm{K}$, interaksi, pemerintah kota, warga

\section{Pendahuluan}

\subsection{Latar Belakang Masalah}

Di era krisis yang melanda Asia, termasuk Indonesia, keberadaan pedagang kaki lima (PKL) merupakan fenomena menarik. Krisis ekonomi yang berlangsung mulai tahun 1997, mengakibatkan kehancuran besar bagi dunia konglomerasi yang umumnya menguasai perekonomian Indonesia. Krisis tersebut melahirkan "generasi" baru dengan status pengangguran, baik berkeahlian maupun tidak. Ketidakseimbangan antara besarnya tenaga kerja yang tersedia dan kesempatan kerja, melahirkan inisiatif baru bagi sebagian anggota masyarakat untuk tetap mempertahankan hidupnya. Salah satu jalan yang ditempuh adalah menjadi PKL, meskipun hal itu bukanlah keinginan mereka yang sesungguhnya.
Kota Bandung, sebagai kota jasa dengan angka pertumbuhan penduduk pada tahun 2000 mencapai 2,54 juta, merupakan pasar potensial bagi pelaku dunia usaha termasuk PKL (Hidayat, Pikiran Rakyat Cyber Media). Kota jasa sebagai prioritas kampanye Pemda Kota Bandung, merupakan dukungan tidak langsung dalam menggairahkan sebagian masyarakat menerjuni usaha berupa PKL.

Dari data statistik yang terkumpul, sebelum tahun 1997, PKL di kota Bandung sekitar 3000 unit, meningkat pada tahun 1997 menjadi 9000 unit dan sungguh dramatis pada tahun 2000 menjadi 16.880 unit. Pertumbuhan dari tahun 1997 sampai tahun 2000 sebesar $56,3 \%$. Tingginya persentase pertumbuhan PKL ini diakibatkan oleh maraknya PHK dan minimnya kesempatan kerja, serta dampak kebebasan dari arus reformasi yang salah diartikan oleh sebagian anggota masyarakat. 
Dari sisi normatif, sebagai pengelola daerah, pemerintah Kota Bandung dapat memanfaatkan keberadaan PKL dalam bidang perdagangan. Namun, kenyataannya, pertumbuhan PKL senantiasa tidak diikuti penataan dan penegakan hukum. PKL melahirkan ketidaknyamanan yang pada gilirannya menimbulkan masalah multidimensi dalam kehidupan sosial masyarakat kota Bandung. Fungsi-fungsi sosial fasilitas umum, telah berganti menjadi tempat usaha, yang hak pengelolaannya berganti tangan.

Komunitas sekitar merasa keberadaan PKL mengganggu kenyamanan, kebersihan, dan ketertiban. Di daerah Cibadak, banyak warga yang mengeluh karena pedagang di Cimol (Cibadak Mall) menutupi toko milik warga dan tidak sedikit pedagang yang buang air sembarangan. Ditambah lagi dengan sampah yang menggunung. Memang Cimol sudah dipindahkan, namun fenomena serupa cukup marak di beberapa titik kota Bandung. Hal ini dapat dilihat di pinggiran pertokoan Jalan Merdeka, Asia Afrika, Dalem Kaum, dan Kepatihan. Hal itu membuat Bandung tidak lagi bisa disebut sebagai kota kembang. Kesemrawutan Kota Bandung tidak sesuai dengan motto genah merenah, tumaninah, dan berhiber (bersih, hijau, dan berbunga).

Ketidaknyamanan warga, pengguna jalan raya dan trotoar akibat kehadiran PKL akan lebih terasa lagi saat memasuki Bulan Ramadhan. PKL bermunculan dengan pesat bak jamur di musim penghujan. Jalan raya dan trotoar tidak lagi sesuai dengan fungsinya, karena PKL memanfaatkannya untuk memajang barang dagangannya.

Untuk itu, yang menjadi permasalahannya sekarang adalah bagaimana usaha pemerintah dalam menanggapi fenomena baru ini dan yang menjadi penekanannya adalah pemahaman bahwa pada saat ini keberadaan PKL dengan pertumbuhan yang begitu cepat tidak bisa dihentikan begitu saja hanya dengan melakukan operasi pembersihan. Mengingat keberadaan mereka tidak lain adalah konsekuensi logis dari kebijakan pembangunan yang salah selama ini dilakukan.

Menurut Soeroso Dasar (1999), secara jujur harus diakui bahwa tanpa mengubah paradigma kebijakan pembangunan maka wacana tentang PKL Kota Bandung usaha yang sia-sia, karena PKL lahir dari rahim pembangunan itu sendiri yang dilegitimasi oleh DPR pada waktu itu. Jadi, pada saat ini yang harus dijadikan pembicaraan bukanlah bagaimana melakukan penataan PKL dan lainnya. Tetapi, lebih pada langkah strategis, mengubah paradigma kebijakan makro yang lebih mengarah pada rakyat kecil karena indikator kemakmuran barometernya bukan in come per kapita, tapi bagaimana distribusi dari pendapatan nasional tersebut ideal tersalurkan.

Yang menjadi pertanyaan lebih lanjut adalah apakah pada saat ini pemerintah telah atau pun mau melakukan perubahan paradigma kebijakan pembangunan, di mana keadilan dan kesejahteraan sosial harus dikedepankan. Dengan kondisi semacam ini, maka berbicara keadilan sosial adalah suatu hal yang menjadi impian abadi bagi masyarakat Indonesia. Karena ekonomi negara, dibangun dengan sistem ekonomi yang memang menguntungkan sebagian kecil masyarakat Indonesia yang mengendalikan sektor modern (formal).

Fenomena di atas memperlihatkan adanya permasalahan di Kota Bandung, yakni terganggunya hubungan antara komunitas, pemerintah kota, dan PKL. Karena itu, perlu kiranya dilakukan penelitian untuk mengkaji masalah yang berkaitan dengan sikap dan perilaku warga komunitas warga mengenai keberadaan PKL di lingkungannya tersebut.

\subsection{Perumusan Masalah}

Tim peneliti merumuskan formulasi masalah penelitian sebagai berikut: "Bagaimana sikap dan perilaku komunitas warga terhadap faktor keamanan, ketertiban, ketenangan, kenyamanan, keindahan, kebersihan, keramahtamahan, mengenai akibat maraknya Pedagang Kaki Lima (PKL)".

\subsection{Kerangka Pemikiran}

Tim peneliti melihat adanya ketidakharmonisan hubungan antara komunitas warga dengan PKL. Harmonis atau tidaknya 
Gambar 1: Pola Komunikasi 3 Pihak

\author{
Pemerintah Kota
}

Komunitas

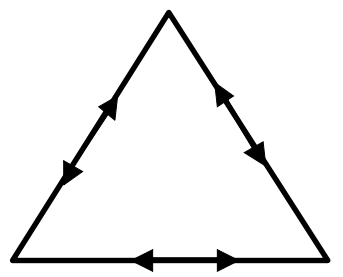

Pedagang Kaki Lima di antaranya, menurut Cutlip \& Center, adalah ketertiban, keamanan, dan perhatian terhadap keselamatan umum (Effendy, 1986: 151). Beberapa hal itulah yang harus dipertimbangkan pemerintah Kota Bandung dalam menangani masalah PKL.

Untuk mengkaji masalah yang akan diteliti ini, peneliti menggunakan teori StimulusOrganisme-Respons (DeFleur, 1970). Efek merupakan reaksi tertentu terhadap stimulus

hubungan antara komunitas dan PKL tentunya tidak lepas pula dari peranan pemerintah kota sebagai pihak yang mengatur berbagai aktivitas PKL di Kota Bandung. Bila dibuat pola komunikasinya, maka akan seperti pada gambar 1 .

Community (komunitas) dapat diartikan sebagai "masyarakat setempat", yaitu dalam rangka mengatur dan memelihara hubungan baik dengan masyarakat setempat (Yulianita, 2000: 77). Dalam perspektif kehumasan (Lesly, 1983: 70), hubungan komunitas merupakan salah satu fungsi humas yang merencanakan kegiatan dan partisipasi yang berkesinambungan antara lembaga dengan komunitas untuk memelihara dan memajukan lingkungan sekitar serta untuk memperoleh keuntungan. Jadi, humas pemerintah turut serta dalam menangani permasalahan terganggunya hubungan antara masyarakat setempat dengan PKL.

Dalam memelihara hubungan yang baik antara komunitas dan PKL, pemerintah harus memperhatikan kepentingan dari komunitas, tiga (rangsangan) tertentu, sehingga orang dapat menduga atau memperkirakan adanya hubungan erat antara stimulus dengan reaksi komunikatenya. Teori ini mempunyai elemen-elemen utama, yakni: (a) sebuah isi pernyataan (stimulus, S); (b) komunikate (organisme, O); dan (c) efek (respons, R). Hubungan antara elemen-elemen tersebut digambarkan pada gambar 2 .

Menurut stimulus respons, efek yang ditimbulkan adalah reaksi khusus terhadap stimulus khusus, sehingga seseorang dapat mengharapkan dan memperkirakan kesesuaian antara pesan dan reaksi komunikate. Jadi, unsurunsur dalam model ini adalah: Pesan (Stimulus, S), Komunikan (Organism, O), dan Efek (Respons, R).

\section{Tinjauan Pustaka}

\subsection{Konsep Sikap dan Perilaku}

Sikap atau attitude adalah "kecenderungan seseorang/sekelompok orang terhadap objek tertentu". Diekspresikan dalam bentuk "sikap

Gambar 2 : Teori S-O-R (DeFleur, 1970)

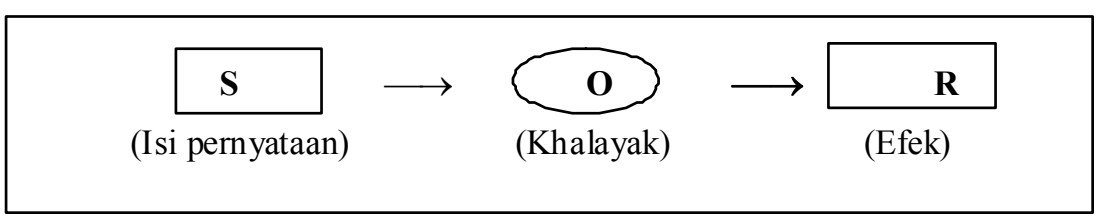


pandangan" atau "sikap perasaan". Ini menunjukkan bahwa sikap seseorang atau sekelompok orang pada tahap selanjutnya disertai "kecenderungannya untuk bertindak sesuai dengan sikap yang objek tadi itu". Jadi, sikap atau attitude akan tepat diartikan sebagai "kecenderungan seseorang melalui kesediaannya beraksi terhadap suatu hal". Ini berarti tidak ada sikap atau attitude tanpa ada objeknya.

Banyak definisi sikap yang disampaikan para pakar, dan dapat ditarik benang merah bahwa sikap merupakan kecenderungan berpikir, merasa, dan bertindak dalam menghadapi suatu objek, ide, situasi, atau nilai. Sikap belum menunjukkan perilaku, tetapi masih berupa kecenderungan untuk berperilaku dengan cara-cara tertentu terhadap objek sikap. Pengertian sikap, yaitu "Sikap bukan perilaku tetapi kecenderungan untuk berperilaku dengan cara-cara tertentu terhadap objek sikap" (Rahmat, 1994:40). Sikap mempunyai 3 komponen, yaitu:

(a) Komponen kognitif, mencakup gagasangagasan yang biasanya digunakan manusia dalam kategori berpikir.

(b) Komponen afektif, mencakup emosi yang mengisi gagasan-gagasan itu.

(c) Komponen konatif, mencakup predisposisi bagi tindakan atau kecenderungan untuk bertindak (Diintisarikan dari Triandis, 1971:26).

Sedangkan perilaku, tingkah laku, atau behavior, secara luas ialah "segala sesuatu yang dilakukan atau dialami seseorang. Dalam pengertian yang lebih sempit, perilaku dapat dirumuskan hanya mencakup reaksi yang dapat diamati secara umum atau objektif' (Chaplin, 1993: 53). Untuk tidak sekadar memahami, tetapi juga agar dapat memprediksi perilaku, Icek Ajzen dan Martin Fishbein mengemukakan "teori tindakan beralasan" (theory of reasoned action). Teori ini berusaha mengungkapkan latar belakang atau alasan (reason) dari suatu tindakan (action). Teori tindakan beralasan mengatakan bahwa sikap mempengaruhi perilaku lewat suatu proses pengambilan keputusan yang teliti dan beralasan.

Nan Lin mendefinisikan perilaku sebagai berikut: "Behavior in contrast to attitude, can be defined as an overt gesture indicating a person's preference and commitment in some observable activity" (Lin, 1977: 145). Selanjutnya, Winardi (1989: 230) menyatakan bahwa: "perilaku pada dasarnya berorientasi pada tujuan". Dengan kata lain, perilaku kita pada umumnya dimotivasi oleh suatu keinginan untuk mencapai tujuan tertentu.

Perilaku dalam penelitian ini lebih ditekankan pada perilaku atau aktivitas-aktivitas dalam arti luas yang juga mencakup perilaku yang tampak (overt behavior) dan perilaku yang tidak tampak (innert) covert behavior) meliputi aktivitas motoris, aktifitas emosional, dan kognitif dari warga komunitas di sekitar lingkungan PKL.

\subsection{Pembentukan dan Perubahan Sikap atau Perilaku}

Pembentukan sikap tidak terjadi dengan sendirinya atau dengan sembarangan. Pembentukannya senantiasa berlangsung dalam interaksi manusia dan berkenaan dengan objek tertentu. Interaksi sosial dalam kelompok maupun di luar kelompok dapat mengubah sikap atau membentuk sikap yang baru. Faktor lain yang turut memegang peranan ialah faktor intern dalam diri pribadi manusia itu, yakni selektivitasnya sendiri, daya pilihnya sendiri, atau minat perhatiannya untuk menerima atau mengolah pengaruhpengaruh yang datang dari luar dirinya itu ditentukan pula oleh motif-motif dan sikap lainnya yang sudah terdapat dalam diri pribadi orang itu. Jadi, dalam pembentukan dan perubahan sikap itu terdapat faktor intern dan faktor ekstern pribadi individu yang memegang peranannya.

\subsection{Konsep "Community Relations"}

Konsep "Community Relations" adalah aktivitas yang dilakukan dalam rangka mengelola hubungan dengan masyarakat atau penduduk di kawasan/sekitar lokasi tertentu. Hubungan dengan masyarakat sekitar tersebut dimulai saat ke luar dari pintu gerbang sampai pada batas masyarakat/ penduduk dalam jarak tertentu, sehingga masyarakat/penduduk sekitar yang dibina hubungannya tersebut dapat memahami 
keberadaan organisasi/kelompok, sehingga mau melindungi, menjaga, peduli terhadap segala permasalahan lingkungannya, di antara kedua belah pihak mau saling membantu, dan mau saling bekerjasama.

Tujuan kegiatan "Community Relations" adalah:

(1) Menciptakan kondisi yang saling mendukung dan saling bekerjasama antar kedua belah pihak.

(2) Untuk dapat beradaptasi dengan masyarakat/ penduduk terdekat.

(3) Mengondisikan keakraban dengan masyarakat/penduduk di sekitar lokasi.

(4) Menunjukkan kepedulian sosial atau tanggung jawab sosial yang tinggi terhadap masyarat terdekat.

(5) Agar organisasi/kelompok tertentu dapat diterima di tengah-tengah masyarakat terdekatnya (Yulianita, 2000).

Hillery(1955), Jonassen (1959), Wills (1977), mendefinisikan komunitas seperti berikut:

(1) sekelompok orang yang hidup dalam (2) suatu wilayah tertentu, yang memiliki (3) pembagian kerja yang berfungsi khusus dan saling tergantung (interdependent), dan (4) memiliki sistem sosial budaya yang mengatur kegiatan para anggota, (5) yang mempunyai kesadaran akan kesatuan dan perasaan-memiliki, serta (6) mampu bertindak secara kolektif dengan cara yang teratur (Hortont \& Hunt, 1999:129).
Definisi yang dianggap ideal oleh Yudistira Garna tentang komunitas adalah: "Suatu kelompok manusia yang menempati suatu kawasan geografis, yang terlibat dalam aktivitas ekonomi, politik dan juga membentuk suatu satuan sosial yang memiliki nilai-nilai tertentu serta rasa kebersamaan"(1999:147).

Membangun komunitas, diperlukan di tengah kemajemukan sebuah wilayah seperti kota Bandung. Heterogenitas dalam etnik, bahasa, kepentingan, struktur, budaya, mengakibatkan masing-masing warga memiliki karakteristik, permasalahan, kondisi manusia, tantangan, dan peluang, serta kebutuhan yang berbeda.

Selanjutnya James N. Rosenau (1974), membedakan tingkat kegiatan dalam proses yang terlibat secara langsung maupun tidak langsung dalam penanganan PKL atau aktor-aktor yang turut serta dalam masing-masing tahapan kegiatan sebagaimana pada gambar 3 .

Untuk memecahkan permasalahan PKL, perlu kiranya menentukan segmen publik secara prioritas dengan "treatment"/strategi yang berbeda. Ditinjau dari penanganan pemda, saat ini mereka dituntut untuk mencapai "good Governance", yaitu kinerja dan akuntabilitasnya secara konsisten dan transparan dituntut oleh publik. Good Governance mengandung arti: Pertama, nilai-nilai yang dapat meningkatkan kemampuan rakyat dalam pencapaian tujuan (nasional), kemandirian, pembangunan yang berkelanjutan, dan keadilan sosial. Kedua, aspek-

\section{Gambar 3 : Tahapan Kegiatan Proses penanganan PKL}

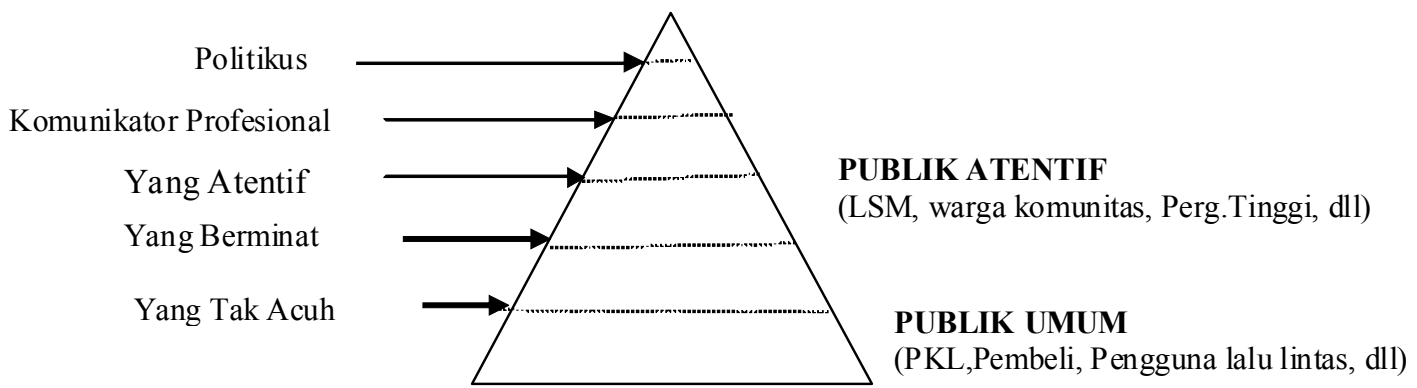


aspek fungsional dari pemerintah yang mangkus dan sangkil dalam pelaksanaan tugasnya untuk mencapai tujuan tersebut.

Prinsip-prinsip yang terkandung dalam upaya mewujudkan good governance meliputi: 1) Kepastian hukum, 2) Keterbukaan, 3) Akuntabilitas, 4) Profesionalitas (Menteri Pendayagunaan Aparatur Negara, 2002).

\section{Tujuan dan Manfaat Penelitian}

\subsection{Tujuan Penelitian}

Tujuan penelitian ini adalah untuk mengetahui, mengkaji, dan menganalisis sikap dan perilaku komunitas warga terhadap faktor keamanan, ketertiban, ketenangan, kenyamanan, kebersihan, keindahan, dan keramah-tamahan yang dirasakan komunitas akibat maraknya PKL, sehingga dapat memberikan masukan bagi Pemerintah Daerah Kota Bandung dalam upaya menyosialisasikan kebijakan pemerintah tentang PKL, khususnya dalam merumuskan konsep kebijakan publik.

\subsection{Manfaat Penelitian}

\subsubsection{Bagi Pengembangan Ilmu (Teoretis)}

Diharapkan dapat bermanfaat dalam mengembangkan ilmu sosial, khususnya ilmu komunikasi, dalam upaya mengkaji hubungan baik dan harmonis dalam suatu komunitas. Selanjutnya, diharapkan dapat mengembangkan konsep community development di lingkungan PKL. Analisis mengenai community relations yang diperoleh dari hasil penelitian ini, di satu sisi, dapat dijadikan bahan masukan yang berharga dalam mengembangkan ilmu hubungan masyarakat khususnya hubungan dengan komunitas, sedangkan di sisi lain untuk menentukan format kebijakan pemerintah kota Bandung tentang PKL.

\subsubsection{Bagi Pengembangan Institusi (Praktis)}

(a) Menawarkan alternatif pemecahan masalah hubungan komunitas akibat maraknya PKL.

(b) Memberikan masukan bagi keberhasilan humas pemerintah dalam mengelola PKL.

(c) Membantu menentukan pola yang tepat dalam permasalahan PKL di kota Bandung. (d) Membantu humas dan pemerintah kota dalam menetapkan strategi komunikasi guna menjembatani hubungan antara komunitas warga sekitar lingkungan PKL dengan PKL.

\section{Metode dan Objek Penelitian}

\subsection{Metode Penelitian}

\subsubsection{Metode Penelitian yang Digunakan}

Tim peneliti menetapkan metode penelitian yang akan digunakan adalah metode survai melalui studi deskriptif analitis, sebagaimana dijelaskan Singarimbun dan Effendi (1995:1): “penelitian survai adalah penelitian yang mengambil sampel dari satu populasi dan menggunakan kuesioner sebagai alat pengumpulan data yang pokok."

\subsubsection{Operasionalisasi Variabel}

Varibel dalam penelitian ini adalah sikap dan perilaku komunitas warga tentang maraknya pedagang kaki lima yang meliputi:

(1) Sikap dan perilaku komunitas warga tentang keamanan, yang menyangkut: (a) ketenteraman (b) tindakan berbahaya atau rawan kriminalitas.

(2) Sikap dan perilaku komunitas warga tentang ketertiban, yang menyangkut: (a) keteraturan; (b) penataan; dan (c) kesemrawutan.

(3) Sikap dan perilaku komunitas warga tentang ketenangan, yang menyangkut: (a) keributan (b) kegaduhan.

(4) Sikap dan perilaku komunitas warga tentang kenyamanan, yang menyangkut: (a) kesehatan (b) kesenangan.

(5) Sikap dan perilaku komunitas warga tentang kebersihan, yang menyangkut: (a) polusi (b) sampah.

(6) Sikap dan perilaku komunitas warga tentang keindahan, yang menyangkut: pemandangan (b) keelokan.

(7) Sikap dan perilaku komunitas warga tentang keramah-tamahan, yang menyangkut: (a ) kondisi yang ramah (b) kondisi interaksi sosial.

\subsubsection{Populasi dan Sampel}

Populasi dalam penelitian ini adalah komunitas warga sekitar lingkungan PKL di tujuh 
titik Rawan PKL sesuai dengan SK Walikota Bandung no. 511/Kep.1322-Huk/2001, yakni: 1) Jl. Kepatihan, 2) Jl. Dalem Kaum dan Jl. Dewi Sartika, 3) Jl. Merdeka, 4) Jl. Asia Afrika, 5) Jl. Oto Iskandar Dinata, 6) Jl. Jenderal Sudirman dan 7) Kawasan Alun-alun Bandung, yang berjarak antara 0 - 100 meter dari lokasi PKL. Berdasarkan data yang diperoleh jumlah warga sekitar di tujuh titik yang berjarak 0 - 100 meter dari lokasi PKL adalah 842 KK. Karena jumlah populasi cukup besar, maka perlu diambil sampel. Penarikan sampel dilakukan dengan teknik random sampling secara proporsional yaitu dengan mengambil sampel sebanyak $10 \%$ dari jumlah komunitas warga yang berada pada jarak 0 - 100 meter di tujuh titik rawan PKL tersebut di atas yaitu sebanyak 10\% x $842=$ $84 \mathrm{KK}$.

\subsection{Objek Penelitian}

Hampir setiap tahun, Pemkot Bandung membersihkan PKL di tujuh titik Kota. Operasi Penertiban dan Penataan PKL seringkali berlangsung serempak di kawasan Jl. Dalem Kaum, Jl. Dewi Sartika, Jl. Asia Afrika, Jl. Kepatihan, Jl. Otto Iskandardinata, Alun-alun, dan Jl. Merdeka. Operasi biasanya melibatkan unsur dari dinas/ instansi/badan di lingkungan Pemkot Bandung plus aparat kewilayahan dan sejumlah organisasi massa di bawah koordinator Kantor Satuan Polisi Pamong Praja. Berbeda dengan operasi-operasi sebelumnya, Wali Kota Bandung Dada Rosada memberi jaminan tidak akan ada PKL di tujuh titik pasca-Lebaran sesuai permintaan masyarakat. Mereka yang membandel akan dikenakan sanksi kurungan maupun denda sesuai Perda 06/1995 tentang Ketertiban, Kebersihan, dan Keindahan (K3) ( Pikiran Rakyat, 29 Nopember 2003).

Berdasarkan S.K. WaliKota no. 511/Kep.1322Huk/2001, operasi pembersihan pertama dilakukan pada bulan Desember tahun 2001. Suasana tanpa PKL (terutama di lokasi yang dibersihkan) sempat dirasakan masyarakat beberapa hari setelah operasi pembersihan berlangsung. Tetapi hari-hari selanjutnya, para PKL kembali menempati lokasi yang telah dibersihkan, walau kadang harus berhadapan dengan aparat Pemda yang ditugaskan untuk menjaga lokasi sebagai bagian dari program Pemda kali ini.

\section{Hasil Penelitian dan Pembahasan}

\subsection{Data Responden}

Terlebih dulu peneliti berupaya untuk mengetahui karakteristik demografi responden melalui pengolahan data responden yang meliputi: jenis kelamin, usia, pendidikan, status marital, pekerjaan, agama, lama menetap, dan jarak lokasi responden dengan lokasi PKL.

\subsection{Data Penelitian}

\subsubsection{Sikap Komunitas Warga tentang PKL}

\section{(1) Sikap komunitas warga tentang Keamanan}

Berdasarkan temuan di lapangan tentang sikap warga komunitas terhadap para PKL, ketika diukur dengan pengetahuan tentang boleh tidaknya mereka berjualan di wilayahnya, hampir seluruhnya menyatakan setuju $(52,38 \%)$ dan sangat setuju $(41,67 \%)$. Artinya, mereka mengetahui dengan pasti bahwa berdasarkan peraturan, PKL tidak boleh berdagang di sekitar tempat mereka tinggal, karena mengganggu ketenteraman lingkungan. Artinya, pengetahuan warga tentang aturan/ regulasi Pemkot Bandung bahwa PKL tidak boleh berjualan di pusat kota atau di 7 titik keramaian kota Bandung, sudah dipahaminya. Menurut pandangan psikologi komunikasi, kognisi atau pengetahuan merupakan tahap awal dalam pembentukan sikap, selain afeksi (emosi), dan konasi (kecenderungan perilaku). Sumber pengetahuan warga komunitas di perkotaan umumnya diperoleh dari media massa dan ini relevan dengan sosialisasi pemerintah kota Bandung yang hampir setiap hari dimuat di surat surat kabar daerah (Harian Umum Pikiran Rakyat, Gala media, Metro, dan Radar Bandung), termasuk tentang penertiban para PKL, sehingga sebagai efeknya, warga Bandung umumnya sudah mengetahui aturan tersebut.

Tapi ketika digali tentang sisi afeksi (emosi) warga komunitas bahwa mereka dan keluarganya merasa terganggu atas kehadiran PKL di 
Tabel 1: Sikap Komunitas Warga tentang Keamanan

\begin{tabular}{|c|c|c|c|c|c|c|c|c|c|c|c|c|}
\hline \multirow{3}{*}{ PERNYATAAN } & \multicolumn{10}{|c|}{ SIKAP RESPONDEN } & \multirow{2}{*}{\multicolumn{2}{|c|}{ Total }} \\
\hline & \multicolumn{2}{|c|}{ SS } & \multicolumn{2}{|c|}{$\mathbf{S}$} & \multicolumn{2}{|c|}{$\mathbf{R}$} & \multicolumn{2}{|c|}{ KS } & \multicolumn{2}{|c|}{ TS } & & \\
\hline & $\mathbf{F}$ & $\%$ & $\mathbf{F}$ & $\%$ & $\mathbf{F}$ & $\%$ & $\mathbf{F}$ & $\%$ & $\mathbf{F}$ & $\%$ & $\mathbf{F}$ & $\%$ \\
\hline $\begin{array}{l}\text { Saya mengetahui bahwa secara peraturan PKL tidak boleh } \\
\text { berdagang di sekitar tempat saya tinggal, karena akan } \\
\text { mengganggu ketentraman lingkungan. }\end{array}$ & 35 & 41,67 & 44 & 52,38 & 1 & 1,19 & 1 & 1,19 & 3 & 3,57 & 84 & 100 \\
\hline $\begin{array}{l}\text { Saya merasa bahwa keberadaan PKL di sekitar tempat saya } \\
\text { tinggal, mengganggu ketentraman kami sekeluarga }\end{array}$ & 26 & 30,95 & 41 & 48,82 & 5 & 5,95 & 6 & 7,14 & 6 & 7,14 & 84 & 100 \\
\hline $\begin{array}{l}\text { Saya menganggap PKL berdagang di sekitar tempat saya } \\
\text { tinggal, tidak menggang gu ketentraman aktivitas se-hari } 2\end{array}$ & 2 & 2,38 & 14 & 16,67 & 11 & 13,10 & 31 & 36,90 & 26 & 30,95 & 84 & 100 \\
\hline $\begin{array}{l}\text { Saya menganggap adanya PKL berdagan g di sekitar tempat } \\
\text { saya tinggal, tidak menimbulkan hal-hal yang berbahaya atau } \\
\text { yang men gundang bahaya. }\end{array}$ & 4 & 4,76 & 14 & 16,67 & 12 & 14,29 & 37 & 44,04 & 17 & 20,24 & 84 & 100 \\
\hline $\begin{array}{l}\text { Saya menganggap bahwa adanya PKL, menjadikan sekitar } \\
\text { tempat saya tinggal, menjadi rawan kriminalitas. }\end{array}$ & 20 & 23,80 & 47 & 55,95 & 5 & 5,95 & 7 & 8,33 & 5 & 5,95 & 84 & 100 \\
\hline $\begin{array}{l}\text { Untuk menjaga ketentraman, Saya pernah mengusulkan pada } \\
\text { ketua RT/RW/Lurah/Camat untuk menertibkan PKL. }\end{array}$ & 24 & 28,57 & 41 & 48,82 & 13 & 15,47 & 5 & 5,95 & 1 & 1,19 & 84 & 100 \\
\hline $\begin{array}{l}\text { Saya pernah punya pengalaman yang negatif tentang PKL, } \\
\text { yang men gusik ketentraman k egiatan seh ari-hari saya }\end{array}$ & 10 & 11,91 & 55 & 65,48 & 8 & 9,52 & 9 & 10,71 & 2 & 2,38 & 84 & 100 \\
\hline $\begin{array}{l}\text { Pengalaman saya, dengan adanya PKL berd agang di sekitar } \\
\text { tempat saya tinggal, mereka dilibatkan untuk kerjasama } \\
\text { keamanan lin gkungan. }\end{array}$ & 6 & 7,14 & 29 & 34,53 & 24 & 28,57 & 17 & 20,24 & 8 & 9,52 & 84 & 100 \\
\hline
\end{tabular}

Ket: $\quad S S=$ Sangat Setuju, $S=$ Setuju, $R=$ Ragu-ragu, KS $=$ Kurang Setuju, TS $=$ Tidak Setuju, $n=84$ Sumber $=$ Angket

lingkungannya, ternyata sebagian besar responden atau sekitar $80 \%$, menyatakan merasa terganggu; dan sebagian kecil responden, yaitu sekitar 20\% tidak merasa terganggu. Sebagai penghuni rumah yang berada di daerah perkotaan, di mana mereka sudah membayar pajak (PBB), uang keamanan, iuran sampah, dan berbagai kewajiban lainnya, maka suatu hal yang wajar jika menuntut hak-nya untuk menikmati hidup tentram. Adanya PKL di sekitar rumah membuat lebih dari setengahnya responden merasa terganggu dalam beraktivitas sehari-hari (ini dinyatakan oleh $36,90 \%$ responden yang merasa terganggu dan 30,95\% responden merasa sangat terganggu), lihat tabel 1.

\section{(2) Sikap Komunitas Warga tentang Ketertiban}

Dari sikap warga komunitas tentang ketertiban pada tabel di atas, terlihat bahwa pengetahuan responden berdasarkan pengalaman dan fenomena yang dapat tertangkap pada umumnya kesemrawutan, ketidakteraturan, dan lingkungan yang acak-acakan, hampir setiap hari dapat terlihat dan dirasakan. Tentu saja hal ini membuat komunitas warga merasa terganggu, dan sangatlah wajar jika sikap yang dimunculkan komunitas warga jelas-jelas tidak setuju dengan adanya PKL di sekitar rumahnya, dengan anggapan PKL berjualan seenaknya ditambah pembeli yang tidak mengindahkan aturan. Dalam situasi seperti ini maka merupakan konsekuensi logis jika komunitas warga mengekspresikan ketidaksetujuannya.

Walaupun demikian lebih dari setengahnya, yaitu sekitar $60 \%$ warga komunitas yang menyatakan sikap tidak keberatan PKL berjualan di sekitar tempat tinggalnya, asalkan mereka berdagang secara teratur dan tempat berjualannya ditata dengan rapi. Dengan demikian sikap ini merupakan salah satu pertimbangan bagi pemkot bahwa pada daerah-daerah tertentu jika memungkinkan, PKL diperbolehkan berjualan tetapi harus ditata sedemikian rupa, sehingga keteraturan dan ketertiban masih bisa dinikmati oleh warga setempat.

Sikap tidak setuju atau tidak suka dengan adanya PKL yang tidak teratur diwujudkan oleh warga komunitas dengan tindakan (perilaku) sebagai berikut: sebagian besar responden, yaitu $58,33 \%$ dan $23,81 \%$ pernah menegur PKL yang menutupi pekarangan rumah warga oleh kios dagangan, lebih dari setengahnya yaitu 44,05\% dan $15,48 \%$ warga menyuruh menertibkan waktu 
Tabel 2: Sikap Komunitas Warga tentang Ketertiban

\begin{tabular}{|c|c|c|c|c|c|c|c|c|c|c|c|c|}
\hline \multirow{3}{*}{ PERNYATAAN } & \multicolumn{10}{|c|}{ SIKAP RESPONDEN } & \multirow{2}{*}{\multicolumn{2}{|c|}{ Total }} \\
\hline & \multicolumn{2}{|c|}{ SS } & \multicolumn{2}{|c|}{$\mathbf{S}$} & \multicolumn{2}{|c|}{$\mathbf{R}$} & \multicolumn{2}{|c|}{$\mathbf{K S}$} & \multicolumn{2}{|c|}{ TS } & & \\
\hline & $\mathbf{F}$ & $\%$ & $\mathbf{F}$ & $\%$ & $\mathbf{F}$ & $\%$ & $\mathbf{F}$ & $\%$ & $\mathbf{F}$ & $\%$ & $\mathbf{F}$ & $\%$ \\
\hline $\begin{array}{l}\text { Dengan adanya PKL berdagang di sekitar } \\
\text { tempat saya tinggal, sepengetahuan saya, } \\
\text { menjadikan lingkungan kami menjadi } \\
\text { semrawut, acak-acakan dan tidak teratur. }\end{array}$ & $\begin{array}{l}3 \\
0\end{array}$ & $\begin{array}{c}35 \\
72\end{array}$ & $\begin{array}{l}5 \\
0\end{array}$ & $\begin{array}{r}59 \\
5 \\
2\end{array}$ & 1 & $\begin{array}{c}1,1 \\
9\end{array}$ & 3 & $\begin{array}{l}3, \\
57\end{array}$ & - & - & $\begin{array}{l}8 \\
4\end{array}$ & $\begin{array}{c}10 \\
0\end{array}$ \\
\hline $\begin{array}{l}\text { Saya menganggap dengan adanya PKL, } \\
\text { lingkung-an saya masih dapat tetap ditata } \\
\text { dengan teratur. }\end{array}$ & 4 & $\begin{array}{c}4,7 \\
6\end{array}$ & 8 & $\begin{array}{c}9, \\
52\end{array}$ & \begin{tabular}{l|}
1 \\
9
\end{tabular} & $\begin{array}{l}22 \\
62\end{array}$ & $\begin{array}{l}3 \\
4\end{array}$ & $\begin{array}{c}40 \\
4 \\
8\end{array}$ & $\begin{array}{l}1 \\
9\end{array}$ & $\begin{array}{c}22 \\
, 6 \\
2\end{array}$ & $\begin{array}{l}8 \\
4\end{array}$ & $\begin{array}{c}10 \\
0\end{array}$ \\
\hline $\begin{array}{l}\text { Saya pernah menegur } P K L \text {, karena ketika } \\
\text { berdagang di sekitar tempat saya tinggal, } \\
\text { mereka membuat lapak/kiosnya yang } \\
\text { menutupi pekarangan rumah/ tempat parkir. }\end{array}$ & $\begin{array}{l}2 \\
0\end{array}$ & $\begin{array}{c}23 \\
81\end{array}$ & $\begin{array}{l}4 \\
9\end{array}$ & $\begin{array}{r}58 \\
3 \\
4\end{array}$ & 6 & $\begin{array}{c}7,1 \\
4\end{array}$ & 3 & $\begin{array}{l}3, \\
57\end{array}$ & 6 & $\begin{array}{c}7 \\
14\end{array}$ & $\begin{array}{l}8 \\
4\end{array}$ & $\begin{array}{c}10 \\
0\end{array}$ \\
\hline $\begin{array}{l}\text { Saya tidak keberatan dengan adanya PKL } \\
\text { berdagang di sekitar tempat saya tinggal, } \\
\text { asalkan mereka membuat dagangannya rapi } \\
\text { dan teratur. }\end{array}$ & 8 & $\begin{array}{c}9,5 \\
2\end{array}$ & $\begin{array}{l}3 \\
3\end{array}$ & $\begin{array}{l}39 \\
, 2 \\
8\end{array}$ & $\begin{array}{l}1 \\
0\end{array}$ & $\begin{array}{l}11 \\
91\end{array}$ & $\begin{array}{l}1 \\
6\end{array}$ & $\begin{array}{c}19 \\
, 0 \\
5\end{array}$ & $\begin{array}{l}1 \\
7\end{array}$ & $\begin{array}{c}20 \\
, 2 \\
4\end{array}$ & $\begin{array}{l}8 \\
4\end{array}$ & $\begin{array}{c}10 \\
0\end{array}$ \\
\hline $\begin{array}{l}\text { Pengalaman saya, para PKL ketika disuruh } \\
\text { mentertibkan waktu dan tempat } \\
\text { berdagangnya, mereka tidak mau } \\
\text { menerima/marah }\end{array}$ & $\begin{array}{l}1 \\
3\end{array}$ & $\begin{array}{c}15 \\
48\end{array}$ & $\begin{array}{l}3 \\
7\end{array}$ & $\begin{array}{r}44 \\
, 0 \\
4\end{array}$ & \begin{tabular}{l|}
1 \\
3
\end{tabular} & $\begin{array}{l}15 \\
48\end{array}$ & 7 & $\begin{array}{l}8, \\
33\end{array}$ & $\begin{array}{l}1 \\
4\end{array}$ & $\begin{array}{c}16 \\
, 6 \\
7\end{array}$ & $\begin{array}{l}8 \\
4\end{array}$ & $\begin{array}{c}10 \\
0\end{array}$ \\
\hline $\begin{array}{l}\text { Saya merasa PKL memang berdagang tanpa } \\
\text { aturan, dan semaunya sendiri, sehingga } \\
\text { mengganggu ketertiban lingkungan }\end{array}$ & $\begin{array}{l}3 \\
1\end{array}$ & $\begin{array}{c}36, \\
91\end{array}$ & $\begin{array}{l}4 \\
7\end{array}$ & $\begin{array}{r}55 \\
9 \\
5\end{array}$ & 1 & $\begin{array}{c}1,1 \\
9\end{array}$ & 4 & $\begin{array}{l}4, \\
76\end{array}$ & 1 & $\begin{array}{l}1, \\
19\end{array}$ & $\begin{array}{l}8 \\
4\end{array}$ & $\begin{array}{c}10 \\
0\end{array}$ \\
\hline
\end{tabular}

Ket: $\quad S S=$ Sangat Setuju, $S=$ Setuju, $R=$ Ragu-ragu, $K S=$ Kurang Setuju, $T S=$ Tidak Setuju $n=84$ Sumber $=$ Angket

dan tempat berdagang PKL. Walaupun sedikit sekali warga lain bersikap apatis, tidak berani menegur atau menyerahkan masalahnya kepada aparat pemerintah setempat.

\section{(3) Sikap Komunitas Warga tentang Ketenangan}

Sikap warga komunitas tentang ketenangan lingkungannya berkaitan erat dengan sikap warga tentang ketertiban. Lebih dari setengahnya responden, yaitu 36,90\% dan 32,14\% menyatakan terganggu atas kegaduhan yang ditimbulkan oleh pedagang; dan hanya sebagian kecil $(3,57 \%$ dan $19,05 \%$ ) yang menyatakan tidak membuat kegaduhan atau kebisingan lingkungan. Suatu kondisi gaduh/ramai otomatis akan tercipta ketika PKL yang berjualan VCD atau kaset memutar musik dagangannya dan tidak hanya satu yang berjualan barang yang sama ditambah PKL tersebut saling bersaing untuk memutar musiknya keras-keras, sehingga sikap yang dimunculkan warga sangat jelas menjadi tidak suka dengan adanya PKL di sekitar rumahnya, karena suasana menjadi tidak tenang dan nyaman.

Sikap tidak setuju atau tidak suka dengan adanya PKL tersebut diwujudkan oleh warga komunitas dengan tindakan (perilaku) sebagai berikut: hampir seluruhnya, yaitu 29,76\% dan $63,10 \%$ akan menegur PKL yang menyetel keraskeras lagu sebagai barang dagangannya dan hanya sedikit sekali, yaitu sekitar 2\% warga komunitas yang tidak berani menegur para PKL yang membuat keributan atau kegaduhan tadi.

\section{(4) Sikap Komunitas Warga tentang Kenyamanan}

Sikap warga komunitas tentang kenyamanan, baik dari pemahaman, perasaan, dan pengalamannya tentang PKL, sebagian besar 
Tabel 3: Sikap Komunitas Warga tentang Ketenangan

\begin{tabular}{|c|c|c|c|c|c|c|c|c|c|c|c|c|}
\hline \multirow{3}{*}{ PERNYATAAN } & \multicolumn{9}{|c|}{ SIKAP RESPONDEN } & \multicolumn{3}{|c|}{ Total } \\
\hline & \multicolumn{2}{|c|}{ SS } & \multicolumn{2}{|r|}{$\mathbf{S}$} & \multicolumn{2}{|r|}{$\mathbf{R}$} & \multirow{2}{*}{$\begin{array}{c}\mathrm{KS} \\
\mathrm{F}\end{array}$} & \multicolumn{2}{|c|}{ TS } & & & \\
\hline & $\mathbf{F}$ & $\%$ & $\mathbf{F}$ & $\%$ & $\mathbf{F}$ & $\%$ & & $\%$ & $\mathbf{F}$ & $\%$ & $\mathbf{F}$ & $\%$ \\
\hline $\begin{array}{l}\text { PKL membuat suasana di lingkungan saya } \\
\text { menjadi ribut/ bising dgn teriakan pedagang dan } \\
\text { pembeli. }\end{array}$ & 22 & $\begin{array}{c}26,1 \\
9\end{array}$ & 44 & 52,38 & 4 & 4,76 & 11 & 13,10 & 3 & 3,57 & 84 & 100 \\
\hline $\begin{array}{l}\text { Saya merasa biasa-biasa saja dan tidak } \\
\text { terganggu dengan kegadu-han para PKL ketika } \\
\text { berdagang. }\end{array}$ & - & - & 14 & 16,67 & $\begin{array}{l}1 \\
2\end{array}$ & 14,29 & 31 & 36,90 & 27 & $\begin{array}{r}32,1 \\
4\end{array}$ & 84 & 100 \\
\hline $\begin{array}{l}\text { Saya akan menegur para PKL jika mereka } \\
\text { menawark an dagan gann ya keras-keras, apalagi } \\
\text { ped agang yan g menggunak an pengeras suara. }\end{array}$ & 24 & $\begin{array}{c}28,5 \\
7\end{array}$ & 40 & 47,62 & $\begin{array}{l}1 \\
0\end{array}$ & 11,91 & 8 & 9,52 & 2 & 2,38 & 84 & 100 \\
\hline $\begin{array}{l}\text { Saya paling benci pada PKL yg berdagang } \\
\text { VCD/Kaset tanpa aturan, dan men yetelnya dgn } \\
\text { semaunya sendiri. }\end{array}$ & 32 & $\begin{array}{c}38,1 \\
0\end{array}$ & 40 & 47,62 & 9 & 10,71 & 3 & 3,57 & - & - & 84 & 100 \\
\hline $\begin{array}{l}\text { PKL yang berjualan di lingkungan saya, umum- } \\
\text { nya tidak membuat kegaduhan atau membuat } \\
\text { kebisingan lingkungan }\end{array}$ & 3 & 3,57 & 16 & 19,05 & $\begin{array}{l}2 \\
2\end{array}$ & 26,19 & 23 & 27,38 & 20 & $\begin{array}{r}23,8 \\
1\end{array}$ & 84 & 100 \\
\hline $\begin{array}{l}\text { Saya akan langsung menegur/melarang jika ada } \\
\text { PKL yan g berjualan } \\
\text { di sekitar saya kemudian membuat kegaduhan ata } \\
\text { keributan }\end{array}$ & 25 & $\begin{array}{c}29,7 \\
6\end{array}$ & 53 & 63,10 & 4 & 4,76 & 1 & 1,19 & 1 & 1,19 & 84 & 100 \\
\hline
\end{tabular}

Ket: $\quad S S=$ Sangat Setuju, $S=$ Setuju, $R=$ Ragu-ragu, KS = Kurang Setuju, TS = Tidak Setuju

$n=84$ Sumber $=$ Angket

Tabel 4: Sikap Komun itas Warga tentang Kenyamanan

\begin{tabular}{|c|c|c|c|c|c|c|c|c|c|c|c|c|}
\hline \multirow{3}{*}{ PERNYATAAN } & \multicolumn{10}{|c|}{ SIKAP RESPONDEN } & \multirow{2}{*}{\multicolumn{2}{|c|}{ Total }} \\
\hline & \multicolumn{2}{|c|}{ SS } & \multicolumn{2}{|c|}{$\mathbf{S}$} & \multicolumn{2}{|c|}{$\mathbf{R}$} & \multicolumn{2}{|c|}{ KS } & \multicolumn{2}{|c|}{ TS } & & \\
\hline & $\mathbf{F}$ & $\%$ & $\mathbf{F}$ & $\%$ & $\mathbf{F}$ & $\%$ & $\mathbf{F}$ & $\%$ & $\mathbf{F}$ & $\%$ & $\mathbf{F}$ & $\%$ \\
\hline $\begin{array}{l}\text { Dengan adanya PKL yang berjualan } \\
\text { di sekitar saya, lingkungan tempat } \\
\text { tinggal menjadi tidak nyaman dan } \\
\text { kumuh }\end{array}$ & 28 & 33,33 & 46 & 54,77 & 2 & 2,38 & 5 & 5,95 & 3 & 3,57 & 84 & 100 \\
\hline $\begin{array}{l}\text { Umumnya ketika para PKL } \\
\text { berdagang, mereka menatanya } \\
\text { dengan a sal-asalan dan tidak tahu } \\
\text { kesehatan lingkungan }\end{array}$ & 25 & 29,76 & 47 & 55,96 & 3 & 3,57 & 4 & 4,76 & 5 & 5,95 & 84 & 100 \\
\hline $\begin{array}{l}\text { Saya akan langsung protes atau } \\
\text { menyatakan keberatan jika ada PKL } \\
\text { yang membuat suasana sekitar jadi } \\
\text { tidak nyaman }\end{array}$ & 37 & 44,05 & 41 & 48,81 & 4 & 4,76 & 1 & 1,19 & 1 & 1,19 & 84 & 100 \\
\hline $\begin{array}{l}\text { PKL yang berjualan di sekitar saya, } \\
\text { u mumnya sudah menata lingkungan } \\
\text { supaya tertib, rapi dan } \\
\text { menyenangkan }\end{array}$ & 4 & 4,76 & 7 & 8,33 & 24 & 28,57 & 35 & 41,67 & 14 & 16,67 & 84 & 100 \\
\hline $\begin{array}{l}\text { Saya merasa senang jika ada PKL } \\
\text { yang menata dan merias dagangan } \\
\text { dan lingkungann ya dengan baik }\end{array}$ & 17 & 20,24 & 37 & 44,05 & 12 & 14,29 & 9 & 10,71 & 9 & 10,71 & 84 & 100 \\
\hline $\begin{array}{l}\text { Saya akan membantu jika ada PKL } \\
\text { yang memin ta tolong untuk men ata } \\
\text { dagangannya agar menjadi tempat } \\
\text { yang indah dan menyen an gkan }\end{array}$ & 3 & 3,57 & 31 & 36,90 & 17 & 20,24 & 20 & 23,81 & 13 & 15,48 & 84 & 100 \\
\hline
\end{tabular}

Ket: $\quad S S=$ Sangat Setuju, $S=$ Setuju, $R=$ Ragu-ragu, $K S=$ Kurang Setuju, TS = Tidak Setuju $n=84 \quad$ Sumber $=$ Angket 
Tabel 5: Sikap Komunitas Warga tentang Kebersihan

\begin{tabular}{|c|c|c|c|c|c|c|c|c|c|c|c|c|}
\hline \multirow{3}{*}{ PERNYATAAN } & \multicolumn{10}{|c|}{ SIKAP RESPONDEN } & \multirow{2}{*}{\multicolumn{2}{|c|}{ Tota I }} \\
\hline & \multicolumn{2}{|c|}{ SS } & \multicolumn{2}{|r|}{$\mathbf{S}$} & \multicolumn{2}{|c|}{$\mathbf{R}$} & \multicolumn{2}{|c|}{$\mathbf{K S}$} & \multicolumn{2}{|c|}{ TS } & & \\
\hline & $\mathbf{F}$ & $\%$ & $\mathbf{F}$ & $\%$ & $\mathbf{F}$ & $\%$ & $\mathbf{F}$ & $\%$ & $\mathbf{F}$ & $\%$ & $\mathbf{F}$ & $\%$ \\
\hline $\begin{array}{l}\text { Dengan adanya PKL yang berjualan di } \\
\text { sekitar saya, lingkun gan tempat tinggal } \\
\text { menjadi kotor dan menjijikkan }\end{array}$ & 23 & 27,38 & 46 & 54,77 & 6 & 7,14 & 7 & 8,33 & 2 & 2,38 & 84 & 100 \\
\hline $\begin{array}{l}\text { Umumnya ketika para PKL berdagang, } \\
\text { mereka jorok dan tidak tahu kebersihan } \\
\text { lingkungan }\end{array}$ & 27 & 32,14 & 46 & 54,77 & 2 & 2,38 & 4 & 4,76 & 5 & 5,95 & 84 & 100 \\
\hline $\begin{array}{l}\text { Saya akan langsung protes atau menyatakar } \\
\text { keberatan jika ada PKL yang mem buang } \\
\text { sampah sembarangan }\end{array}$ & 36 & 42,86 & 47 & 55,95 & - & - & 1 & 1,19 & - & - & 84 & 100 \\
\hline $\begin{array}{l}\text { PKL yang berjualan di sekitar saya, } \\
\text { umumnya memahami tentang kebersihan } \\
\text { lingkungannya }\end{array}$ & 1 & 1,19 & 8 & 9,52 & 31 & 36,91 & 24 & 28,57 & 20 & 23,81 & 84 & 100 \\
\hline
\end{tabular}

Ket: $\quad S S=$ Sangat Setuju, $S=$ Setuju, $R=$ Ragu-ragu, $K S=$ Kurang Setuju, $T S=$ Tidak Setuju $n=84$ Sumber $=$ Angket

(33,33\% dan 54,76\%) menyatakan lingkungan menjadi tidak nyaman dan kumuh. Selain itu, sebagian besar $(29,76 \%$ dan $55,95 \%)$ warga menyatakan penataan dagangan PKL asal-asalan dan tidak tahu kesehatan lingkungan. Sikap yang dimunculkan sebagian kecil warga melalui tindakan-tindakan terhadap PKL di sekitar rumahnya; adalah akan membantu mereka jika diminta untuk menata dagangan atau mau bekerja sama (antara 10-24\%).

\section{(5) Sikap Komunitas Warga tentang Kebersihan}

Sikap warga komunitas tentang kebersihan, sebagian besar responden, yaitu $27,38 \%$ dan $54,77 \%$ menyatakan lingkungan menjadi kotor dan menjijikan dan para PKL jorok dan tidak tahu kebersihan lingkungan (32,14\% dan 54,77\%). Sikap tidak setuju atau tidak suka dengan kejorokan dan kekotoran lingkungan yang disebabkan oleh PKL tersebut diwujudkan oleh warga komunitas dengan tindakan (perilaku) memprotes atau menegur PKL yang membuang sampah seenaknya, atau mengotori lingkungan di sekitar rumah warga. Sikap warga tersebut dinilai wajar untuk menjaga kebersihan, oleh karena kebersihan lingkungan akan berkaitan erat dengan kesehatan.

\section{(6) Sikap komunitas warga tentang Keindahan}

Sikap warga komunitas tentang keindahan walaupun bersifat relatif, tetapi sebagian besar

Tabel 6: Sikap Komunitas Warga tentang Keindahan

\begin{tabular}{|c|c|c|c|c|c|c|c|c|c|c|c|c|}
\hline \multirow{3}{*}{ PERNYATAAN } & \multicolumn{10}{|c|}{ SIKAP RESPONDEN } & \multirow{2}{*}{\multicolumn{2}{|c|}{ Total }} \\
\hline & \multicolumn{2}{|c|}{ SS } & \multicolumn{2}{|c|}{$\mathbf{S}$} & \multicolumn{2}{|c|}{$\mathbf{R}$} & \multicolumn{2}{|c|}{ KS } & \multicolumn{2}{|c|}{ TS } & & \\
\hline & $\mathbf{F}$ & $\%$ & $\mathbf{F}$ & $\%$ & $\mathbf{F}$ & $\%$ & $\mathbf{F}$ & $\%$ & $\mathbf{F}$ & $\%$ & $\mathbf{F}$ & $\%$ \\
\hline $\begin{array}{l}\text { PKL seringkali ketika berdagang di sekitar tempat saya } \\
\text { tinggal, m ereka menggantung-gantungkan barang } \\
\text { dagangannya dengan sembarangan }\end{array}$ & 17 & 20,24 & 42 & 50,00 & 5 & 5,95 & 14 & 16,67 & 6 & 7,14 & 84 & 100 \\
\hline $\begin{array}{l}\text { Saya tidak keberatan PKL berdagang di sekitar tempat } \\
\text { saya tinggal, asalkan mereka tidak merusak keindahan } \\
\text { sekitar }\end{array}$ & 6 & 7,14 & 31 & 36,90 & 16 & 19,05 & 17 & 20,24 & 14 & 16,67 & 84 & 100 \\
\hline $\begin{array}{l}\text { Pengalaman saya, para PKL marah ketika disuruh } \\
\text { menata barang dagang ann ya ag ar elok dilihat }\end{array}$ & 12 & 14,29 & 25 & 29,76 & 27 & 32,14 & 13 & 15,48 & 7 & 8,33 & 84 & 100 \\
\hline $\begin{array}{l}\text { Saya mera sa PKL tidak peduli dengan keindahan } \\
\text { lingkungannya }\end{array}$ & 25 & 29,77 & 49 & 58,33 & 4 & 4,76 & 4 & 4,76 & 2 & 2,38 & 84 & 100 \\
\hline
\end{tabular}

Ket $: \quad S S=$ Sangat Setuju, $S=$ Setuju, $R=$ Ragu-ragu, $K S=$ Kurang Setuju, TS = Tidak Setuju, $n=84$

Sumber $=$ Angket 
yaitu 20,24\% dan 50,00\% warga komunitas tidak senang jika PKL menggantung-gantungkan barang dagangannya seenaknya, termasuk menyimpan barang dagangannya di halaman rumah warga. Sikap tidak setuju atau tidak suka bahwa PKL tersebut tidak mempedulikan keindahan lingkungan, diwujudkan oleh warga komunitas melalui teguran-teguran agar tidak merusak keindahan pekarangan rumah warga.

\section{(7) Sikap Komunitas Warga tentang Keramahtamahan}

Sikap warga komunitas terhadap PKL secara manusiawi ternyata cukup peka. Lebih dari setengahnya warga bertegur sapa dengan para PKL; walaupun sebagian kecil menyatakan tidak perlu atau tidak pernah bertegur sapa. Hanya sebagian kecil yang menyatakan PKL tadi orangnya ramah-ramah. Seperti ketika dilakukan wawancara mendalam dengan warga di sekitar Jl. Oto Iskandardinata, ternyata warga senang jika PKL itu warga Bandung atau Jawa Barat yang "baik-baik", tapi tidak suka dengan orang pendatang yang umumnya kasar dan tidak tahu sopan santun. Jadi, keramahtamahan ini tidak bisa disamaratakan di antara semua PKL. Namun, satu sisi yang sama bahwa para PKL harus mampu beradaptasi dengan warga komunitas setempat untuk memperoleh dukungan terhadap mata pencahariannya tersebut.

\subsubsection{Perilaku Komunitas Warga tentang Keberadaan PKL}

(1) Perilaku komunitas warga tentang keamanan.

Perilaku responden bila PKL mengganggu ketentraman lingkungan, ketentraman keluarga, ketentraman aktivitas sehari-hari, atau bila keberadaan PKL menimbulkan bahaya, menjadi rawan kriminalitas, umumnya: menegur, mengusir, dan menertibkan, bertindak sesuai aturan perda, melarang berjualan, memohon bantuan aparat atau pihak berwajib. Umumnya responden membantu aparat untuk menertibkan. Jika PKL mau bekerjasama, umumnya responden mau melakukan tindakan kerjasama dan ikut berpartisipasi. Sebagian kecil tetap protes dengan alasan PKL suka seenaknya bila dilibatkan dalam kerjasama lingkungan.

(2) Perilaku komunitas warga tentang ketertiban.

Bila PKL membuat lingkungan semrawut, acakacakan, dan tidak teratur, membuat lapak/kios yang menutupi pekarangan/tempat parkir, umumnya responden melakukan tindakan: menegur dan memberitahu mereka, mengusir, menertibkan, memprotes, marah, kesal dan melaporkan pada aparat sesuai dengan

Tabel 7: Sikap Komunitas Warga tentang Keramahtamahan

\begin{tabular}{|c|c|c|c|c|c|c|c|c|c|c|c|c|}
\hline \multirow{3}{*}{ PERNYATAAN } & \multicolumn{10}{|c|}{ SIKAP RESPONDEN } & \multirow{2}{*}{\multicolumn{2}{|c|}{ Total }} \\
\hline & \multicolumn{2}{|r|}{ SS } & \multicolumn{2}{|c|}{$\mathbf{S}$} & \multicolumn{2}{|c|}{$\mathbf{R}$} & \multicolumn{2}{|c|}{ KS } & \multicolumn{2}{|c|}{ TS } & & \\
\hline & $\mathbf{F}$ & $\%$ & $\mathbf{F}$ & $\%$ & $\mathbf{F}$ & $\%$ & $\mathbf{F}$ & $\%$ & $\mathbf{F}$ & $\%$ & $\mathbf{F}$ & $\%$ \\
\hline $\begin{array}{l}\text { Saya tidak pernah bertegur sapa dgn para PKL, karena } \\
\text { mereka sendiri acuh tak acuh }\end{array}$ & 10 & 11,91 & 38 & 45.23 & 15 & 17,86 & 17 & 20,24 & 4 & 4,76 & 84 & 100 \\
\hline $\begin{array}{l}\text { Para PKL yg berdagang di sekitar tempat saya tinggal } \\
\text { mereka baik-baik danramah-ramah }\end{array}$ & - & - & 19 & 22,61 & 32 & 38,10 & 23 & 27,38 & 10 & $\begin{array}{c}11,9 \\
1\end{array}$ & 84 & 100 \\
\hline $\begin{array}{l}\text { Pengalaman saya, interaksi PKL dgn penduduk di sekital } \\
\text { bisa terjalin dengan baik }\end{array}$ & 2 & 2,38 & 13 & 15,48 & 36 & 42,86 & 19 & 22,61 & 14 & $\begin{array}{c}16,6 \\
7\end{array}$ & 84 & 100 \\
\hline Saya merasa PKL sama dgn kita bisa diajak berkawan & 4 & 4,76 & 40 & 47,61 & 26 & 30,95 & 7 & 8,33 & 7 & 8,33 & 84 & 100 \\
\hline
\end{tabular}

Ket: $\quad S S=$ Sangat Setuju, $S=$ Setuju, $R=$ Ragutragu, $K S=$ Kurang Setuju, $T S=$ Tidak Setuju, $n=84$

Sumber $=$ Angket 
peraturan setempat. Bila dengan adanya PKL, lingkungan masih dapat tetap ditata dengan teratur, membuat dagangannya rapi dan teratur, umumnya responden melakukan tindakan positif yakni: membantu keberadaan PKL asal tidak mengganggu, membiarkan tetap berjualan, mengadakan musyawarah dengan PKL supaya lebih tertib. Sebagian kecil responden tetap melarang atau menolak, bahkan pesimis jika PKL bisa tetap menjaga lingkungan. Sedangkan bila PKL tidak mau/ marah ketika disuruh menertibkan waktu dan tempat berdagangnya atau bila PKL berdagang tanpa aturan dan semaunya sendiri, umumnya responden melaporkan pada aparat, menegur, mengusir, meminta untuk pindah ke tempat lain, protes, dan memberi saran kepada PKL.

(3) Perilaku komunitas warga tentang ketenangan.

Dengan adanya PKL, suasana lingkungan menjadi ribut/bising, membuat kegaduhan ketika berdagang, menawarkan dagangannya keras-keras, apalagi menggunakan pengeras suara, membuat kegaduhan atau keributan, pada umumnya responden: menegur atau memperingatkan agar tidak ribut, menertibkan, mengusir, ditindak tegas, memasang pemberitahuan, menggerutu, melarang, dan melaporkan pada aparat setempat. Bila PKL umumnya tidak membuat kegaduhan atau kebisingan yang dilakukan responden adalah: sebagian kecil tidak melakukan apa-apa, membiarkan (asal sesuai dengan peraturan, di lokasi khusus), ada pula yang tetap mengusir dan menolak PKL, kalaupun mereka tidak membuat gaduh hanya bersifat sementara, namun demikian ada pula responden yang menghargai PKL.

(4) Perilaku komunitas warga tentang kenyamanan.

Bila PKL membuat lingkungan tidak nyaman dan kumuh, menata dagangan dengan asalasalan dan tidak tahu kesehatan lingkungan, membuat suasana sekitar tidak nyaman, umumnya: menegur, mengusir, menertibkan, marah, memasang pengumuman/peringatan, meminta PKL untuk membersihkan kembali dagangan dan kotorannya, dan melaporkan pada aparat setempat. Bila PKL sudah menata lingkungan supaya tertib, rapi, menyenangkan, menata dan merias dagangan serta lingkungan dengan baik, umumnya responden melakukan tindakan yang sifatnya membiarkan saja (asal selalu rapi, sesuai peraturan), mendukung, dan memberikan saran, atau sebaliknya tetap mengusir (karena tidak setuju ada PKL).

(5) Perilaku komunitas warga tentang kebersihan.

Bila PKL membuat lingkungan kotor dan menjijikan, jorok, membuang sampah sembarangan, umumnya responden: memperingatkan, mengusir, menindak, dan melaporkan ke aparat setempat atau pihak berwenang. Jika PKL umumnya memahami tentang kebersihan lingkungan antara lain: dengan tidak membuang sampah sembarangan, meninggalkan tempat berjualannya dalam keadaan bersih, yang dilakukan responden adalah: lebih dari setengahnya mendukung asal sesuai peraturan dan ditempatkan di lokasi khusus, membiarkan, dan sebagian kecil tetap menolak ada PKL bahkan tetap mengusir.

(6) Perilaku komunitas warga tentang keindahan.

Bila PKL menggantung-gantung barang dagangannya dengan sembarangan, marah ketika disuruh menata dagangannya, atau tidak peduli dengan keindahan lingkungan sekitar, pada umumnya responden: menegur, mengusir, atau melarang berjualan karena tidak setuju ada PKL, memberikan saran, memakluminya, dan ada pula yang melaporkan pada pihak aparat setempat. Bila PKL tidak merusak keindahan sekitar lingkungannya, yang dilakukan responden adalah: mau membantu, mendukung, dan menghargai 
keberadaan PKL dengan syarat sesuai peraturan dan ditempatkan di lokasi khusus, sebagian kecil responden lainnya tetap mengusir karena mereka tidak setuju di lingkungannya ada PKL.

(7) Perilaku komunitas warga tentang keramahtamahan.

Perilaku responden berdasarkan bila PKL acuh tak acuh yakni: tidak pernah bertegur sapa dengan penduduk sekitar, arogan, bersikap tidak mau tahu, yang dilakukan responden adalah: menegur, mengusir, acuh lagi, marah, dan menindak tegas, memberi pengarahan/ pengertian kepada PKL, sebagian kecil lainnya melaporkan ke pihak terkait. Sedangkan bila PKL baik dan ramah, interaksi PKL dengan penduduk bisa terjalin dengan baik, atau PKL bisa diajak berkawan, pada umumnya responden melakukan tindakan yang menghargai PKL, berlaku baik dan berlaku ramah lagi, mau mendukung, mau mempertahankannya, dan bahkan mau dijadikan teman supaya harga dagangannya bisa murah.

\section{Kesimpulan dan Saran}

\subsection{Kesimpulan}

(1) Sikap dan perilaku komunitas warga tentang faktor keamanan.

Umumnya sikap responden dan keluarganya merasa terganggu atas kehadiran PKL di lingkungannya, PKL bisa mengundang atau menimbulkan bahaya, lingkungan menjadi rawan kriminalitas. Responden tidak setuju untuk bekerjasama dengan alasan apapun. Sebagian besar responden melakukan teguran, mengusir, menertibkan, dan mereka mendukung dan mau membantu tindakan aparat untuk menertibkan.

(2) Sikap dan perilaku komunitas warga tentang faktor ketertiban.

Hampir seluruh responden menyatakan lingkungan menjadi semrawut, acak-acakan, dan tidak teratur; namun mereka tidak keberatan PKL berjualan di lingkungannya, asalkan teratur dan ditata rapi. Di sisi lain, mereka kesal pada PKL yang menutupi pekarangan rumah warga oleh kios dagangan, hal ini memunculkan sikap apriori terhadap PKL. Umumnya, responden melakukan teguran dan memberitahu mereka, menertibkan, bahkan mengusir, memprotes, marah dan kesal, atau melaporkan ke aparat setempat agar ditindak sesuai peraturan yang berlaku. Namun, jika PKL mau menata dagangannya secara teratur dan rapi, mereka tidak berkeberatan asal tidak mengganggu, dan mau bermusyawarah dengan PKL supaya lebih nyaman. Di sisi lain, ada responden yang tetap melarang PKL berjualan di lingkungannya.

(3) Sikap dan perilaku komunitas warga tentang faktor ketenangan.

Lebih dari setengahnya responden merasa terganggu atas kegaduhan yang ditimbulkan oleh PKL. Umumnya, melakukan teguran atau memperingatkan PKL, memasang pemberitahuan, menggerutu, mengusir, menindak tegas, dan melarang atau melapor ke pihak terkait/ berwenang. Namun, sebagian kecil responden menghargai dan mendukung PKL, asal PKL mengikuti aturan, dan mereka sepakat jika pemerintah menempatkan PKL di lokasi khusus. Sebagian kecil responden tetap menolak dan tetap ingin mengusir PKL.

(4) Sikap dan perilaku komunitas warga tentang faktor kenyamanan.

Sebagian besar responden menyatakan dengan adanya PKL lingkungan menjadi tidak nyaman dan kumuh, penataan dagangan asalasalan dan mengganggu kesehatan. Namun, ada responden yang mau membantu, mendukung, atau bekerja sama jika diminta untuk menata dagangan PKL di sekitar rumahnya. Umumnya, responden menegur, menertibkan, meminta untuk membersihkan, melaporkannya ke aparat setempat, memasang 
pengumuman/ peringatan, bahkan mengusir. Namun, jika PKL mau menata lingkungannya dengan tertib, rapi, dan menyenangkan, maka mereka mau membantu dan memperbolehkan dengan syarat lingkungan selalu dijaga kebersihan dan kerapihannya.

(5) Sikap dan perilaku komunitas warga terhadap faktor kebersihan.

Sebagian besar responden menyatakan bahwa dengan keberadaan PKL, lingkungan menjadi kotor dan menjijikan dan jorok. Umumnya, responden menegur atau memperingatkannya, bahkan mengusir, dan melaporkan ke aparat setempat. Umumnya responden mau membantu asal PKL mau mengikuti aturan dan mau ditempatkan di lokasi yang disediakan pemerintah.

(6) Sikap dan perilaku komunitas warga terhadap faktor keindahan.

Sebagian besar warga komunitas tidak senang jika PKL menggantung-gantungkan barang dagangan seenaknya, termasuk menyimpan barang dagangannya di halaman rumah warga. Mereka tidak setuju jika PKL tidak mempedulikan keindahan lingkungan dan bahkan merusak pekarangan rumah warga. Umumnya, responden memberikan saran, menegur, melaporkan pada pihak terkait atau aparat setempat, bahkan mengusirnya. Bila PKL tidak merusak keindahan lingkungan, responden mau membantu dan mau menghargai, asal sesuai dengan peraturan yang berlaku dan para PKL mau ditempatkan di lokasi khusus.

(7) Sikap dan perilaku komunitas tentang faktor keramahtamahan.

Lebih dari setengahnya responden menyatakan mau bertegur sapa dengan para PKL walaupun hanya bersifat basa-basi; dari segi keramahtamahan, umumnya PKL ramahramah. Umumnya, responden menegur, memberi pengarahan/pengertian kepada PKL, bahkan marah-marah, mengusirnya, dan melaporkan ke pihak terkait atau aparat setempat. Namun jika PKL baik-baik dan ramah, maka responden mau menghargai, bersikap baik, ramah pada PKL, mendukung, mempertahankannya, dijadikan teman supaya harga bisa murah.

\subsection{Saran}

\subsubsection{Saran Pengembangan Ilmu}

Hasil penelitian ini hanya dapat meng-cover sikap dan perilaku komunitas warga sekitar PKL terhadap eksistensi PKL, maka untuk penelitian mendatang diharapkan juga dapat diteliti bagaimana sikap dan perilaku $P K L$ sesuai eksistensinya, sehingga dapat memenuhi keinginan komunitas warga sekitarnya, juga harapan dan keinginan Pemerintah Kota Bandung. Dengan harapan penelitian berikut dapat menggali keberadaan PKL yang tidak saja dianggap menguntungkan dirinya, tapi juga menguntungkan komunitas warga dan memelihara lingkungan sekitarnya, dalam arti tidak selalu dianggap mengganggu, sehingga kedua belah pihak dapat membina hubungan yang simbiosis mutualistis.

\subsubsection{Saran Pengembangan Praktis}

(1) Agar hubungan antara komunitas warga sekitar PKL, PKL, dan Pemerintah Kota, dapat terjalin dengan harmonis, maka sebaiknya setiap kelompok berupaya untuk dapat menghargai kebutuhannya dan mau mengerti keinginan, harapan masing-masing pihak, sehingga konsep Wwn-win solution dapat tercapai secara baik.

(2) Kesadaran untuk dapat menjaga 7 "K" tidak saja muncul dari PKL, tapi juga dari warga sekitar PKL, juga Pemerintah Kota. Semua pihak menyadari bahwa 7 "K" merupakan hal penting yang harusdiaplikasikan secara konsisten dan konsekuen.

\section{Daftar Pustaka}

Azwar, Saifuddin. 1988. Sikap Manusia; Teori dan Pengukurannya. Yogyakarta: Liberty. 
BPS (Badan Pusat Statistik). 2001. Jawa Barat dalam Angka. Propinsi Jawa Barat.

Chaplin. Cp. 1981. Dictionary of Psychology. New York: Dell, Publ. Terj. Kartono, Kartini. 1993. Kamus Lengkap Psikologi. Cetakan Kedua. Jakarta: Rajagrafindo Persada.

Cutlip, Scott M., Allen H. Center, and Glen M. Broom. 1994. Effective Public Relations. Seventh Edition. New Jersey: Prentice Hall International, Inc.

2000. Effective Public Relations. Eighth Edition. New Jersey: Prentice Hall International, Inc.

DeFleur, Melvin L. dan Sandra Ball-Rokeach. 1982. Theories of Mass Communication. $5^{\text {th }}$ Edition. New York: Longman Inc.

Effendy, Onong Uchjana. 1986. Dinamika Komunikasi. Bandung: Remadja Karya.

1993. Ilmu, Teori \& Filsafat Komunikasi. Bandung: PT. Citra Aditya Bakti.

Garna, Yudistira K., 1992. Teori-Teori Perubahan Sosial. Bandung: Program Pascasarjana, Universitas Padjadjaran.

1999. Ilmu-ilmu Sosial Dasar-Konsep - Posisi, Bandung: Primaco Akademika.

Hidayat, Pikiran Rakyat Cyber Media.

Horton, Paul B. \& Hunt, Chester L. 1999. Sociology, terjemahan Amirudin Ram \& Tita Sobari, Jakarta: Erlangga.

Lesly, Philip. 1983. Everything You Wanted to Know about Public Relations. Singapore: Mubaruk \& Brothers PTE.

Lin, Nan. 1977. The Study of Human Communication. New York: The Bobbs Merill Corp.

Marát. 1982. Sikap Manusia Perubahan serta Pengukurannya. Jakarta: Graha Indonesia.
Maciver, R.M. \& Charles H. Page, 1961. Society, An Introductory Analysis, London: Macmillan \& Co Ltd.

Mueller, Daniel J. 1986. Measuring Social Attitudes; A Handbook for Researchers and Practioners. New York: Teachers College Press.

Rakhmat, Jalaluddin. 1989. Psikologi Komunikasi. Edisi Revisi. Bandung: Remadja Karya.

- 1999. Metode Penelitian Komunikasi; Dilengkapi Contoh Analisis Statistik. Bandung: Remaja Karya.

Rubin, Herbert J. \& Rubin, Irene S. 1992, Community Organizing and Development, USA: Mcmillan Publishing Company.

Singarimbun, dan Sofyan Effendi (Editor), 1995. Metode Penelitian Survai. Jakarta: LP3ES.

Soekanto, Soerjono, 1990. Sosiologi Suatu Pengantar. Jakarta: RajaGrafindo Persada.

Winardi. 1989. Perilaku Organisasi (Organizational Behavior). Bandung: Tarsito.

Yulianita, Neni. 2000. Dasar-Dasar Public Relations. Bandung: Alqaprint Jatinangor.

\section{Bacaan Lain-lain:}

Harian Umum Pikiran Rakyat, 3 Desember 2004.

Kompas.Com tanggal 8 Januari 2002.

Pikiranrakyat.Com tanggal 8 Januari 2002

Pikiranrakyat.Com tanggal 7 November 2002

Pikiranrakyat.Com tanggal 30 Januari 2003

Pikiranrakyat.Com tanggal 27 Februari 2003

Pikiranrakyat.Com tanggal 11 Maret 2003 